\title{
Fungicides of biological and chemical origin to control grape alternariosis
}

\author{
Yevgenia Galkina*, Natalia Aleinikova, Vladimir Andreyev, Elena Bolotianskaia, and \\ Vladimir Shaporenko \\ ${ }^{1}$ FSBSI All-Russian National Research Institute of Viticulture and Winemaking Magarach of the RAS, \\ 31 Kirova str., 298600 Yalta, Republic of Crimea, Russia
}

\begin{abstract}
At the modern stage of development, the support of sustainable viticulture is possible having an optimal set of methods and means of effective disease control. Currently, with distribution and development of grape leaf alternariosis, the issue of forming a zonal assortment of fungicides by replenishing with preparations that effectively regulate the causative agent of this grape disease in addition to basic diseases - mildew and oidium, is updated. The paper presents the results of laboratory and field studies aimed at finding effective means of biological and chemical origin to control the development of grape alternariosis. The maximum antifungal activity against Alternaria sp. for the period of 2016-2020 in vitro was showen by 2 biological preparations based on OPS and OST-713 strains of the bacterium Bacillus amyloliquefaciens, as well as by active agents from triazole and strobilurin chemical classes. Field studies of 2018-2020 found out that the minimum values of aternariosis development on leaves were obtained with three-fold application of fungicides Skor, EC (0.4 l/ha), Acrobat Top, WDG (1.5 kg/ha), Dynali, DC (0.6 1/ha), Quadris, SC (0.6 1/ha), Topaz, EC (0.4 $1 /$ ha), as well as when using the biological preparation Serenade ASO, SC (5.0 1/ha). The obtained results allow to conclude that fungicides of both biological and chemical origin, intended for protection of grapes from basic diseases, can be used to effectively control grape alternariosis.
\end{abstract}

\section{Introduction}

At the modern stage of development, the support of sustainable viticulture [1] is possible if the optimal set of methods and means of effective disease control, including the fungicides of chemical and biological origin, is existing [2]. In the conditions of climate change, in addition to basic, ubiquitous grape diseases (oidium, mildew and gray rot), the emergence of new, distribution and development of previously insignificant diseases is observed [3-5]. According to the long-term study results of phytosanitary situation on plantations of the main viticultural zones of Crimea, an increase in the intensity of grape alternariosis development was established. When determining the influence of grape affection by this disease on the quantitative and qualitative characteristics of the yield in 2019-2020, its harmfulness is

\footnotetext{
*Corresponding author: galkinavine@mail.ru
} 
shown [6]. The obtained data correspond with the research results of scientists in other viticultural regions of Russia and worldwide [7, 8, 9, 11] and confirm the relevance of development a set of actions aimed at effective control of grape alternariosis, including the search for effective fungicides of biological and chemical origin.

In national and international publications, there is some information on the in vitro study results of the efficiency of chemical fungicides, biological preparations and plant extracts against the causative agent of grape alternariosis. Good antimycotic activity was confirmed for such active agents of fungicides as 8-oxyquinoline sulfate (Quinosol, P), kresoxim-methyl (Stroby, WDG), difenoconazole + flutriafol (Medea, ME), cyprodinil + iprodione (AVG 0210) [11], fludioxonil + cyprodinil (Switch, WDG) [12], thiophanate-methyl (Topsin-M, WP), fosetyl-aluminum (Aliette, WP), mandipropamid (Revus, SC), neem, aloe vera and eucalyptus extracts [8], as well as pinnata essential oil [10]. High antifungal activity in laboratory and field conditions was demonstrated by biological preparations Trichodermin Nova (T. viride, strain 4097), as well as 18 strains of Bacillus genus on Tylona-3 medium, 3 strains of 9 bacteria of Pseudomonas genus on Kinga B medium and strains 3-3 Bacillus sp., K 1-1 Bacillus sp. on potato-sucrose agar [13].

The purpose of this research was to find modern effective means of chemical and biological origin to control the development of alternariosis on grape plantations of the Crimea.

\section{Materials and methods}

Isolation and identification of the pathogen associated with grape alternariosis, screening of fungicides and biological preparations for biological efficiency in vitro were carried out in the plant protection laboratory using standard methods described in national and foreign literature $[8,13]$. The study of morphological and cultural characteristics of filamentous fungi isolated in pure culture from grape leaves infected with alternariosis showed their attribution to the Alternaria section and most likely to Alternaria alternate or A. tenuissima [14]. The studied fungicides and biological preparations are currently registered or pass the registration stage to be used on grapes to control mildew, oidium and gray rot in the Russian Federation in concentrations corresponded to the recommendations of manufacturers.

Field experiments were carried out under the conditions of stationary experiment on plantations of the 'Aligote' grape variety, which leaves are intensively affected by alternariosis (JSC Agrofirma Chernomorets, South-Western Crimea) against the natural background of disease development. Experimental plot of the 'Aligote' variety is of 2003 planting year, stock 'Berlandieri x Riparia Kober 5BB', planting pattern - 3x3 (0.3) m, bush training - one-sided cordon, open-earth, rain-fed culture. The experiments were set up and the accounting was carried out according to the methods generally accepted in viticulture and plant protection; each variant consisted of 8 registered bushes in 4 replicates ( 2 bushes per replicate) [15]. The experimental data obtained were analyzed using methods of descriptive statistics and Microsoft Excel worksheets. The confidence coefficient level of statistical analysis was $0.95(95 \%)$.

The scheme of field experiment in 2018-2020 included fungicides from chemical classes of strobilurins, triazoles, morpholines, quinones, mandelamides, benzamides and biological preparations, showed good efficacy in the control of Alternaria sp. in vitro. Spraying was provided three times: the first - "berries pea-sized", 27.06-03.07, the next - "bunches begin to develop", 11-15.07, and "bunches end to develop", 25-31.07. The study of preparations was carried out in comparison with the non-treated control and the standard (table 1). 
Table 1. The scheme of field experiment on the study of biological efficiency of fungicides in protecting grapes from alternariosis

(The 'Aligote' grape variety, JSC Agrofirma Chernomorets), 2019-2020

\begin{tabular}{|c|c|c|c|}
\hline No. & Fungicide (years) & Acting agent & $\begin{array}{c}\text { Application } \\
\text { rate }\end{array}$ \\
\hline 1 & $\begin{array}{c}\text { Standard - Quadris, } \\
\text { SC } \\
(2019-2020)\end{array}$ & Azoxystrobin, $250 \mathrm{~g} / \mathrm{l}$, strobilurins & $0.8 \mathrm{l} / \mathrm{ha}$ \\
\hline 2 & Skor, EC (2019) & Difenoconazole, $250 \mathrm{~g} / \mathrm{l}$, triazoles & $0.4 \mathrm{l} / \mathrm{ha}$ \\
\hline 3 & $\begin{array}{c}\text { Acrobat Top, WDG } \\
(2019-2020)\end{array}$ & $\begin{array}{c}\text { Dimethomorph, } 150 \mathrm{~g} / \mathrm{kg}+\text { dithianon, } \\
350 \mathrm{~g} / \mathrm{kg}, \text { morpholines, quinones }\end{array}$ & $1.5 \mathrm{~kg} / \mathrm{ha}$ \\
\hline 4 & $\begin{array}{c}\text { Pergado Zox, WDG } \\
(2019-2020)\end{array}$ & $\begin{array}{c}\text { Mandipropamid, } 250 \mathrm{~g} / \mathrm{kg}+\text { zoxamide, } \\
240 \mathrm{~g} / \mathrm{kg}, \text { mandelamides, benzamides }\end{array}$ & $0.6 \mathrm{~kg} / \mathrm{ha}$ \\
\hline 5 & $\begin{array}{c}\text { Dynali, DC } \\
(2019-2020)\end{array}$ & $\begin{array}{c}\text { Difenoconazole, } 60 \mathrm{~g} / 1+\mathrm{cyflufenamid}, \\
30 \mathrm{~g} / \mathrm{l}, \mathrm{triazoles}\end{array}$ & $0.61 / \mathrm{ha}$ \\
\hline 6 & Topaz, EC (2020) & Penconazole, $100 \mathrm{~g} / 1$, triazoles & $0.4 \mathrm{l} / \mathrm{ha}$ \\
\hline 7 & $\begin{array}{c}\text { Altasal Uni, SC } \\
(2020)\end{array}$ & Mefentrifluconazole, $75 \mathrm{~g} / 1$, triazoles & $1.5 \mathrm{l} / \mathrm{ha}$ \\
\hline 8 & $\begin{array}{c}\text { Serenade ASO, SC } \\
(2020)\end{array}$ & $\begin{array}{c}\text { Bacillus amyloliquefaciens, strain OST- } \\
713, \text { titer not less than } 1 \times 10^{9} \mathrm{CFU} / \mathrm{ml}\end{array}$ & $5.0 \mathrm{l} / \mathrm{ha}$ \\
\hline
\end{tabular}

\section{Results and discussion}

In general, for the period of 2016-2020, a very good efficiency (95\% and higher) against the causative agent of alternariosis - micromycete Alternaria sp., isolated in a pure culture from grape leaves among 28 tested fungicides, was registered for 6 preparations, good efficiency $(75-95 \%)$ - for 13 ones. Active agents from chemical classes of triazoles and strobilurins were the most effective. Screening of 9 biological preparations and biologically active compounds allowed revealing of 2 preparations with consistently very good efficiency - OPS and OST-713 strains of the bacterium Bacillus amyloliquefaciens.

The antifungal activity of fungicides Skor, EC, Quadris, SC and Zato, WDG on the 5th and 10th day was at the level of $100 \%$, of the preparation Manage, WP $-98.4 \%$ and $99.1 \%$. Fungicide Altasal Uni, SC controlled growth of Alternaria sp. on potato-glucose agar with an efficiency of $100 \%$ on the 5 th day, and $89.2 \%$ on the 10 th day. Using of the preparation Migiva, SC made it possible to inhibit the development of the studied micromycete with an efficiency of $90.6 \%$ and $86.9 \%$. The innovative two-component preparation Dynali, DC (difenoconazole, $60 \mathrm{~g} / 1+$ cyflufenamid, $30 \mathrm{~g} / 1$ ) was keeping growth control of colonies with an efficiency of $78.5-82.3 \%$. The results obtained agree with the data of national and foreign researchers $[8,12]$.

When studying the fungicidal activity of biological preparations, a high biological activity in controlling the development of alternariosis was established, this indicator was at the level of $96-100 \%$ both on the 5 th and 10th day of cultivation with preparations Serenade ASO, SC and Orgamika S, W. The obtained results make it possible to recommend the studied fungicides and biological preparations for field experiments.

Field experiments of 2019-2020 on the study of biological efficiency of modern fungicides and biological preparations in the control of grape alternariosis allowed obtaining the experimental data presented in table 2 .

In 2019, against the background of increased temperature regime in June (average daily air temperatures reached $24-27^{\circ} \mathrm{C}$, with an absolute maximum of $35.6^{\circ} \mathrm{C}$ ), the development of alternariosis on grape leaves of the 'Aligote' variety was observed with an intensity of $8 \%$ 
starting from the third decade (25.06). Moderate air temperatures $\left(17.9-24.8{ }^{\circ} \mathrm{C}\right.$ ) and precipitation in July mildly contributed to the disease development - in the first decade (9.07) the leaves of the control variant were affected with an intensity of $13.6 \%$, in the third decade (23.07) and at the beginning of August (02.08) the development of the disease has decreased to $12.1 \%$ and $11.2 \%$, respectively (table 2 ). An increase in the development of alternariosis on leaves up to $25.4 \%$ was registered in the middle of August (15.08).

Table 2. The efficiency of using fungicides in protecting grapes from alternariosis in the conditions of South-Western Crimea

(The 'Aligote' grape variety, JSC Agrofirma Chernomorets)

\begin{tabular}{|c|c|c|c|c|c|c|}
\hline Variant & D.D, $\%$ & B.E., $\%$ & D.D, \% & B.E., $\%$ & D.D., $\%$ & B.E., $\%$ \\
\hline \multicolumn{7}{|c|}{2019} \\
\hline & \multicolumn{2}{|c|}{9.07} & \multicolumn{2}{|c|}{23.07} & \multicolumn{2}{|c|}{02.08} \\
\hline Control & 13.6 & - & 12.1 & - & 11.2 & - \\
\hline Standard - Quadris, SC & 3.0 & 78.0 & 2.8 & 76.8 & 2.6 & 76.8 \\
\hline Acrobat Top, WDG & 3.3 & 75.7 & 2.5 & 79.3 & 2.0 & 82.1 \\
\hline Pergado Zox, WDG & 3.6 & 73.5 & 3.4 & 71.9 & 3.1 & 72.3 \\
\hline Dynali, DC & 3.0 & 77.9 & 2.8 & 76.8 & 2.4 & 78.6 \\
\hline Skor, EC & 2.6 & 80.9 & 2.4 & 80.2 & 1.4 & 87.5 \\
\hline $\mathrm{LCD}_{05}$ & 0.8 & - & 0.7 & - & 1.1 & - \\
\hline \multicolumn{7}{|c|}{2020} \\
\hline & \multicolumn{2}{|c|}{9.07} & \multicolumn{2}{|c|}{21.07} & \multicolumn{2}{|c|}{05.08} \\
\hline Control & 13.4 & - & 15.8 & - & 23.0 & - \\
\hline Standard - Quadris, SC & 3.4 & 74.6 & 4.6 & 70.9 & 6.6 & 71.3 \\
\hline Acrobat Top, WDG & 2.5 & 81.3 & 2.9 & 81.6 & 5.9 & 74.3 \\
\hline Pergado Zox, WDG & 3.6 & 73.1 & 4.2 & 73.5 & 6.1 & 73.5 \\
\hline Dynali, DC & 2.9 & 78.4 & 3.0 & 81.1 & 5.1 & 77.8 \\
\hline Topaz, EC & 3.1 & 76.9 & 3.0 & 81.0 & 5.1 & 77.8 \\
\hline Altasal Uni, SC & 3.2 & 76.1 & 3.9 & 75.3 & 6.4 & 72.2 \\
\hline Serenade ASO, SC & 3.4 & 74.6 & 5 & 68.4 & 7.4 & 67.8 \\
\hline $\mathrm{LCD}_{05}$ & 0.7 & - & 0.8 & - & 0.94 & - \\
\hline
\end{tabular}

Notice: D.D. - disease development; B.E. - biological efficiency

Under the hydrothermal conditions of the growing season of 2020, against the background of moderate air temperatures in June, the first cases of leaf damage by alternariosis were noted on 23.06 to a very weak degree (1.8\%). At elevated air temperatures in the first and third decades of July, against the background of insufficient humidification, the intensity of disease development increased to $13.4 \%(9.07)$ and $23 \%$ (5.08), a slight growth of this indicator to $26 \%$ by 21.08 was due to moderate temperatures in the second decade of August (table 2).

In 2019 , the minimum values of the disease development on leaves (1.4-2.6\%) were registered when using the fungicide Skor, EC (0.4 1/ha). In variants with the use of fungicides Dynali, DC (0.6 1/ha) and Acrobat Top, WDG $(1.5 \mathrm{~kg} / \mathrm{ha})$, the intensity of leaf damage did not exceed $2.4-3 \%$ and $2.2-3.3 \%$. When using the preparation Pergado Zox, WDG $(0.5$ $\mathrm{kg} / \mathrm{ha}$ ), the infestation of grape leaves by alternariosis was 3.6\% (9.07), 3.4\% (23.07) and $3.1 \%(2.08)$. In the standard variant (three-fold application with the fungicide Quadris, SC, $0.81 /$ ha), the disease development on leaves varied within $2.6-3 \%$ (table 2 ).

Therefore, the biological efficiency of the fungicide Skor, EC in protection of the 'Aligote' grape leaves from alternariosis was high and amounted to 80.2-87.5\%. Three-fold treatment with fungicides Dynali, DC and Acrobat Top, WDG made it possible to control the disease development at the level of $76.8-78.6 \%$ and $75.7-82.1 \%$, which corresponded to the 
standard (76.8-78\%). The biological efficiency of using Pergado Zox, WDG from the beginning of alternariosis development in phenological growth stages "berries pea-sized", "bunches begin to develop" and "bunches end to develop" was 72-73.5\% (table 2).

The analysis of data of 2020 showed the least alternariosis development on the 'Aligote' grape leaves when using fungicides Acrobat Top, WDG (1.5 kg/ha), Dynali, DC (0.6 1/ha) and Topaz, EC (0, 4 1/ha) - 2.5-5.9\%, 2.8-6.1\% and 3.1-5.1\%, respectively. In the variants with the use of Altasal Uni, SC and the biological preparation Serenade ASO, SC, the intensity of leave affection was 3.2-6.4\% and 3.4-7.4\%. When using the preparation Pergado Zox, WDG (0.5 kg/ha), the development of alternariosis was 3.6\% (9.07), 4.2\% (21.07) and $7.1 \%$ (5.08). Three-fold application of the fungicide Quadris, SC (0.8 1/ha) made it possible to control the disease at the level of 3.4-6.6\% (table 2).

Thus, the three-fold application of the studied fungicides after the beginning of alternariosis development on leaves in the phenological growth stages "berries pea-sized", "bunches begin to develop" and "bunches end to develop" made it possible to obtain biological efficiency for Acrobat Top, WDG (1.5 kg/ha), Dynali, DC (0.6 1/ha) and Topaz, EC $(0.41 / \mathrm{ha})$ at the level of $74.3-81.3 \%, 73.5-79.1 \%$ and $76.9-81,0 \%$, respectively. The fungicide Altasal Uni, SC and biological preparation Serenade ASO, SC controlled the disease development at the level of 72.2-76.1\% and 67.8-74.6\%. In the standard this indicator was within the range of 70.9-78.4\%. The biological efficiency of using the Pergado Zox, WDG was $69.1-73.1 \%$ (table 2).

\section{Conclusion}

As a result of a series of laboratory experiments in 2016-2020, aimed at finding effective means of chemical and biological origin to control the development of grape alternariosis, a high anti-myotic activity of fungicides was established: class of triazoles - Manage, WP (imibenconazole, $150 \mathrm{~g} / \mathrm{kg}$ ), Altasal Uni, CS (mefentrifluconazole, $75 \mathrm{~g} / 1$, isopropylazole subgroup), Skor, EC (difenoconazole, $250 \mathrm{~g} / \mathrm{l}$ ), Dynali, DC (difenoconazole, $60 \mathrm{~g} / \mathrm{l}+$ cyflufenamid, $30 \mathrm{~g} / \mathrm{l}$ ); class of strobilurins - Quadris, SC (azoxystrobin, $250 \mathrm{~g} / \mathrm{l}$ ), Zato, WDG (trifloxystrobin, $500 \mathrm{~g} / \mathrm{kg}$ ); innovative preparation Migiva, SC (kinoprol, $200 \mathrm{~g} / \mathrm{l}$ ); biological preparations Serenade ASO, SC (Bacillus amyloliquefaciens, strain OST-713, titer not less than $1 \times 10^{9} \mathrm{CFU} / \mathrm{ml}$ ) and Orgamika S, W (Bacillus amyloliquefaciens, strain OPS-32, titer not less than $\left.5 \times 10^{9} \mathrm{CFU} / \mathrm{ml}\right)$.

Field experiments in 2019-2020 showed that fungicides Skor, EC, Acrobat Top, WDG, Dynali, DC, Topaz, EC were the most effective in inhibiting the development of alternariosis, good results were achieved with the use of Altasal Uni, SC, Quadris, SC, biological preparation Serenade ASO, SC. The study of fungicides Altasal Uni, SC, Topaz, EC and biological preparation Serenade ASO, SC should be continued.

Thus, for effective control of grape alternariosis, both biological and chemical fungicides can be used to protect grapes from oidium and mildew.

\section{References}

1. E. Egorov, Z. Shadrina, G. Kochyan, V. Kudryakov, E3S Web Conf., 254, 10007 (2021) https://doi.org/10.1051/e3sconf/202125410007

2. S. Das, S. Pattanayak, Int. J. Curr. Microbiol. App. Sci., 9(5), 993-1005 (2020) https://doi.org/10.20546/ijcmas.2020.905.109

3. R.S. Jayawardena, W. Purahong, W. Zhang, T. Wubet, X.H.Li, M. Liu, W. Zhao, K. D. Hyde, J.H. Liu, J. Yan, Fun. Diver., 90, 1-84 (2018) https://doi.org/10.1007/s13225-018$\underline{0398-4}$ 
4. R.S. Jayawardena, K.D. Hyde, K.W.T. Chethana, D.A. Daranagama, I.D. Goonasekara, I.S. Manawasinghe, A. Mapook, S.C. Jayasiri, A. Karunarathna, C.G. Li, C. Phukhamsakda, I.C. Senanayake, D.N. Wanasinghe, E. Camporesi, T.S. Bulgakov, X.H. Li, M. Liu, W. Zhang, J.Y. Yan, Mycosphere, 9(1), 1-114 (2018) https://doi.org/10.5943/mycosphere/9/1/1

5. N. Girsova, N. Aleinikova, T. Kastalyeva, Y. Radionovskaya, D. Bogoutdinov, BIO Web Conf., 25, 06004 (2020)https://doi.org/10.1051/bioconf/20202506004

6. N.V. Aleinikova, Ye.S. Galkina, E.A. Bolotianskaya, V.V. Andreiev, V.N. Shaporenko, P.A. Didenko, Magarach. Viticulture and Winemaking, 23(1), 43-48 (2021) https://doi.org/10.35547/IM.2021.33.55.007

7. K. Rantsiou, S. Giacosa, M. Pugliese, V. Englezos, I. Ferrocino, S. R. Segade, M. Monchiero, I. Gribaudo, G. Gambino, M. Lodovica Gullino, L. Rolle, Front. Plant Sci., 11, 700 (2020) https://doi.org/10.3389/fpls.2020.00700

8. M.U. Khana, M.A. Abroa, G.H. Jatoia, A. Alic, M.H. Hulliod, L.D. Guob, Biocell, 43(2), 12-21 (2019)

9. Ch. Wijekoon, Z. Quill, Canad. J. Microbio., 67(1), 29-36 (2021) https://doi.org/10.1139/cjm-2020-0293

10. A. Sajid, G. Irshad, F. Naz, S. Ghuffar, I. Hassan N. Mahmood, K. Rani, M. F. Manzoor, A. Meesam, A. M. Hamzah, M. Z. Karamt, A. J. Agric, Biol., 8(2), 168-173 (2020) https://doi.org/10.35495/ajab.2019.11.532

11. M. Burovinskaya, E. Urchenko, Fruit Growing and Viticulture of South Russia, 58(04), 146-165 (2019) https://doi.org/10.30679/2219-5335-2019-4-58-146-165

12. E.Jankura, L'.Piknová, J.Štefániková, Conference: 42nd World Congress of Vine and Wine July (2019) https://www.researchgate.net/publication/336318016

13. M. Burovinskaya, L. Maslienko, E. Yurchenko, E3S Web Conf., 254, 05004 (2021) https://doi.org/10.1051/e3sconf/202125405004

14. P.B. Gannibal, Mycotaxon, 130(4), 941-949 (2015) https://doi.org/10.5248/130.941

15. E. Ostroukhova, N. Aleinikova, I. Peskova, E. Galkina, E. Bolotianskaia, O. Zaitseva, E3S Web Conf., 254, 05002 (2021) https://doi.org/10.1051/e3sconf/202125405002 